\title{
RESEARCH OF POLLUTION'S LEVEL OF THE ARAZ RIVER BY XENOBIOTICS AND PATHOGENIC MICROORGANISMS, CHEMICAL AND RADIOLOGICAL WAYS OF PURIFICATION OF WATER'S SAMPLES
}

\author{
Kh.F.Mamedov, A.M.Gulamirov, R.G.Garibov, G.R.Allahverdiyev, H.N.Shiraliyeva, \\ A.R.Alihuseynova, N.A.Mirzayev \\ Institute of Radiation Problems of Azerbaijan National Academy of Sciences \\ xagani06@mail.ru
}

Received 29.03.2017

\begin{abstract}
Measurement of radiation background in nearby territories along the watercourse of Araz river and comprehensive sensory, analitico-chemical, physico-chemical and microbiological analyses of samples of the river water are carried out. The optimum parameters of chemical and radiological disinfection and purification of water samples polluted by anthropogenous xenobiotics and pathogenic microorganisms are determined.
\end{abstract}

Keywords: xenobiotics, radionuclides, heavy metals, microorganisms, radiological disinfection.

Important aspect of solution of the ecological safety problems of vegetable products is to study the accumulation of toxic elements in water, soil and vegetable. The accumulation of great quantities of toxicants in the soil leads generally to intake of these substances in a human body by water- migratory and translocation ways [1-10].

Pollution of the soil and the larger rivers flowing through the territory of the country by various anthropogenous emissions promote to increase of the content of xenobiotics in objects of the environmental nature. Increase of technogenic pressure upon the objects of surrounding nature, operation of natural reserves leads to emergence of zones with a critical ecological situation in the territory of the republic. Therefore, there is a need for carrying out the complex (radiological, chemical, biological) monitorings for providing accumulation of objective information on a condition of the environment and allowing to predict tendencies, speeds of emergence of ecological dangers and the happening changes on the territory of the Azerbaijan Republic, including those on the border territories.

Installations of electron accelerators and gamma radiation of ${ }^{60} \mathrm{Co}$ and ${ }^{137} \mathrm{Cs}$ radioactive sources are successfully used in various areas of radiation-chemical technology, for purification and disinfection of the water sources polluted by anthropogenous emissions [9-11].

As a result of determination of level of pollution by anthropogenous various organic and inorganic emissions (xenobiotics) of one of the largest rivers of Azerbaijan having contacts with territories of three other neighboring countries, using results of the conducted researches appear possibilities for planning preventive and directive actions and carrying out the processes of chemical and radiological purification and disinfection of water.

\section{Methodical part}

Identification and determination of quantities of the reactants used in experiments, the analyzed anthropogenous organic and inorganic emissions, harmful chemicals, heavy metals, radionuclides are carried out besides traditional analytico-chemical methods, also using modern research physico-chemical methods.

For sampling of water there were used in advance sterilized dishess and sampling, transportation and storage of samples of water were carried out according to requirements of standards 24481-80 and 18968-73. In addition to radiometric measurements were carried out the express analyses with microbiological test napkins and sensory assays in all possible cases on places of sampling of water. To determine the conformity of water samples to the requirements of standards 2874-82, AZS 216-2006, AZS 282-2007 for "Drinking Water" the comprehensive sensory, analytico-chemical, physico-chemical and bacteriological analyzes were conducted in accordance with the requirements of standards 2761-84, 3351-74, 2874-82, 18164-72, 4151-72, 4011-72, 4245-72, 4386-81, 18963-73, 4595-49, 18826-73, 18190-72. 
Microbiological rapid tests were carried out with a test napkins manufactured by $\mathrm{R}$ Biopharm (Germany) and equipped with certificates of the quality control system ISO 9001 and 13485. Determination of the microorganism's count and types in stationary laboratory conditions was carried out using selective culture media produced by Hi-Media (India) and Condalab (Spain), incubators with automated thermostats and colony counters [4].

Radiometric indicators were measured using produced by "Canberra" corporation radiometers "Radiagem-2000" equipped with alpha, beta and gamma radiation detectors and "Inspector1000 " measuring the density of ionizing radiation and rate of the dose and produced by corporation "ThermoScientific" portable radiometeridentifier "IdentiFINDER", which measures dose rate and identifies radioactive isotopes.

For conducting physico-chemical analyzes of water and mineral of water samples were used the steam sterilizers "LDZX-30FBS" and "Tengor", the "GFL-2304" biodisstilator, the "TDL$5 \mathrm{M}^{\prime}$ and "TD5A-WS" centrifuges, the "Canber$\mathrm{ra}^{\prime \prime}$ gamma spectrometer with HPGe germanium detector, scanning electron microscope "SEM" with X-ray tube, "XRF" X-ray fluorescence spectrometer, laboratory electronic scales, $\mathrm{pH}$ meters, derivatograph, automatic micropipettes equipped with appropriate tips, laboratory mixing-heating tiles, bulb heaters, heat-resistant glass and ceramic laboratory glassware, laboratory refrigerators and evaporators, metal paws and tripods, Petri-cups, colony counters, membrane filters and other laboratory analytical and chemical installations and equipment.
Irradiation of water samples was carried out at stationary radiation research facilities (absorbed dose rate $0.0045,0.18 \mathrm{~Gy} / \mathrm{s}$ or $\left.2.81 \cdot 10^{13}, 1.12 \cdot 10^{15} \mathrm{eVg}^{-1} \mathrm{~s}^{-1}\right)$. The method of irradiating samples by ionizing radiation is described in detail in previous publications [2-5].

\section{The discussion of the results}

Complex sensory, analytico-chemical, physico-chemical and microbiological analyzes of samples of water, soil and vegetation were conducted in stationary laboratory conditions, the presence of anthropogenic xenobiotics and their amounts in soil and water samples were studied, as well as cases of contamination of these samples with toxic substances, radionuclides and microorganisms.

Concentrations of chemical trace elements determined by analytico-chemical and physico-chemical analyzes in soil samples taken from the surrounding Araz landscape in Nakhchivan city, Sadarak and Ordubad regions of the Nakhchivan Autonomous Republic and in the Beylagan district are shown in Table 1.

Concentrations of chemical trace elements determined by analytico-chemical and physicochemical analyzes in vegetation samples (trees, leaves and small branches of bushes, flowers and grass) taken from the surrounding Araz landscape in Nakhchivan city, Sadarak and Ordubad regions of the Nakhchivan $A R$ and in the Beylagan district are shown in Table 2.

The radioactive background and the types of radioactive radiation were detected in the territory of the Nakhchivan AR and the degree of contamination by radionuclides of the Araz river along the territory of the Azerbaijan Republic was determined.

Table 1. Concentrations of trace elements in soil samples taken from the surrounding Araz landscape

\begin{tabular}{|c|c|c|c|c|}
\hline Elements & $\begin{array}{c}\text { In the soil of the Sadarak } \\
\text { region, mg/kg }\end{array}$ & $\begin{array}{c}\text { In the soil of the Nakh- } \\
\text { chivan city, mg/kg the soil of the Ordu- }\end{array}$ & $\begin{array}{c}\text { In the soil of the Bey- } \\
\text { bagan district, } \mathrm{mg} / \mathrm{kg}\end{array}$ \\
\hline Sulphates & 1440 & 148 & 180 & 113 \\
\hline $\mathrm{Chlorides}$ & 260 & 106 & 127 & 111 \\
\hline $\mathrm{Na}, \mathrm{K}$ & 220,120 & 207,109 & 193,500 & 35,71 \\
\hline $\mathrm{CaCO} 3$ & 6587 & 707 & 1408 & 0.05 \\
\hline $\mathrm{Br}$ & 0.2 & 0.02 & 10 & 0.02 \\
\hline $\mathrm{Sr}$ & 18 & 12 & $0.2,0.1$ & $0,0.03$ \\
\hline $\mathrm{Ti}, \mathrm{Zr}$ & 0,0 & $0.1,0.1$ & $5.5,0.3$ & $1.7,0.05$ \\
\hline $\mathrm{Fe}, \mathrm{P}$ & $5.7,0.7$ & $3.4,0.1$ & 0.05 & 0.02 \\
\hline $\mathrm{Zn}$ & 0.05 & 0.02 & 0.005 & 0.004 \\
\hline $\mathrm{As}$ & 0.03 & 0.005 & & \\
\hline
\end{tabular}


Table 2. Concentrations of trace elements in vegetation taken from the surrounding Araz landscape

\begin{tabular}{|c|c|c|c|c|}
\hline Elements & $\begin{array}{c}\text { In the soil of the Sadarak } \\
\text { region, } \mathrm{mg} / \mathrm{kg}\end{array}$ & $\begin{array}{c}\text { In the soil of the Nakh- } \\
\text { chivan city, } \mathrm{mg} / \mathrm{kg}\end{array}$ & $\begin{array}{c}\text { In the soil of the Ordu- } \\
\text { bad region, } \mathrm{mg} / \mathrm{kg}\end{array}$ & $\begin{array}{c}\text { In the soil of the Beylagan } \\
\text { district, } \mathrm{mg} / \mathrm{kg}\end{array}$ \\
\hline Sulphates & 477 & 366 & 380 & 342 \\
\hline $\mathrm{K}$ & 6462 & 5567 & 9075 & 5885 \\
\hline $\mathrm{Ca}$ & 7645 & 933 & 9675 & 9755 \\
\hline $\mathrm{Sr}$ & 104 & 97 & $0.2,0.1$ & $0.1,0.03$ \\
\hline $\mathrm{Ti}, \mathrm{Zr}$ & $0.1,0$ & $0.1,0.1$ & $1,0.9$ & $3,0.4$ \\
\hline $\mathrm{Fe}, \mathrm{P}$ & $14,1.7$ & $8,0.7$ & 1.1 & 0.6 \\
\hline $\mathrm{Zn}$ & 1.1 & 0.6 & 0 & 14 \\
\hline $\mathrm{As}$ & 0.007 & 0 & 15 & 0 \\
\hline $\mathrm{Mn}$ & 18 & 6.7 & & 14 \\
\hline
\end{tabular}

Alpha and beta radiation were not detected from water samples taken from the Araz river.

The measured dose rate from the natural radioactive background varies in the range $0.031-0.082 \mu \mathrm{Sv} / \mathrm{h}$ (the maximum permissible value is $0.12 \mu \mathrm{Sv} / \mathrm{h}$ ), and the alpha radiation intensity is within $0-0.11 \mathrm{~Bq}_{\mathrm{eq}} / \mathrm{cm}^{2}$.

The measured dose rate from the natural radioactive background was detected in the surrounding Araz landscape in the territory of the Beylagan and İmishli regions varies in the range $0.031-0.042 \mu \mathrm{Sv} / \mathrm{h}$ and the alpha radiation intensity is $0 \mathrm{~Bq}_{\mathrm{eq}} / \mathrm{cm}^{2}$.

The concentration of the ${ }^{22} \mathrm{Na}$ isotope (radiation intensity) in the upper and lower parts of stream of the Araz river along the territory of the Nakhchivan AR respectively is $0.40-0.54$ $\mathrm{Bq} / \mathrm{l}$ and $0.44-0.58 \mathrm{~Bq} / \mathrm{l}$, while the concentration of the ${ }^{40} \mathrm{~K}$ isotope (radiation intensity) varies respectively in the intervals $0.26-0.29 \mathrm{~Bq} / \mathrm{l}$ and $0.30-0.44 \mathrm{~Bq} / \mathrm{l}$.

The concentration of the ${ }^{22} \mathrm{Na}$ isotope (radiation intensity) in the upper and lower parts of stream of the Araz river along the territory of the Beylagan-Imishli regions respectively is $0.32 \mathrm{~Bq} / \mathrm{l}$ and $0.38 \mathrm{~Bq} / \mathrm{l}$, while the concentration of the ${ }^{40} \mathrm{~K}$ isotope (radiation intensity) varies respectively in the intervals $0.18 \mathrm{~Bq} / 1$ and $0.22 \mathrm{~Bq} / \mathrm{l}$.

For comparison, the concentration of the isotope ${ }^{22} \mathrm{Na}$ (radiation intensity) in the samples of drinking water supplied to enterprises and for population in the cities of Nakhchevan and Ba$\mathrm{ku}$ respectively is $0.32 \mathrm{~Bq} / \mathrm{l}$ and $0.28 \mathrm{~Bq} / \mathrm{l}$, and the concentration of the isotope ${ }^{40} \mathrm{~K}$ respectively is $0.18 \mathrm{~Bq} / \mathrm{l}$ and $0.16 \mathrm{~Bq} / \mathrm{l}$ (these values are low results typical for natural spring waters), the dose rate of gamma radiation on the natural radioactive background in these cities varies respectively in the intervals $0.045-0.071 \mu \mathrm{Sv} / \mathrm{h}$ and $0.011-0.045 \mu \mathrm{Sv} / \mathrm{h}$, the intensity of alpha radiation varies respectively in the intervals $0-0.01$ $\mathrm{Bq}_{\mathrm{eq}} / \mathrm{cm}^{2}$ and $0-0.04 \mathrm{~Bq}_{\mathrm{eq}} / \mathrm{cm}^{2}$.

To identify areas along the path of the Araz River, where there are sources of pollution, at the crossing of the Sadarak region of the Nakhchivan Autonomous Republic with bordering of Turkey and Armenia and after the Customs Transition Gate, at the intersection of the territory of the Ordubad region with the borders of the Iranian Islamic Republic (IIR) and Armenia, and further on, at the site of crossing the territory of the Beylagan district with the boundary of the IIR the samples were removed in accordance with the requirements of the relevant standards, conducted radiometric measurements, sensory and express analyzes. The microbiological analysis of water samples was carried out on the same day already under stationary laboratory conditions, i.e. incubation of microorganisms of water was carried out at the corresponding temperatures in the appropriate selective culture media and further analyticochemical and physico-chemical researches were conducted.

For the comparative demonstration of the ecological state, chemical, radiological and bacteriological indicators, the results of a comprehensive analysis of drinking water supplied to enterprises and population of the city of $\mathrm{Na}$ khchivan are shown on the Table 3, next to the results of analyzes of water samples taken from the above sections of the Araz river. 
Table 3. The results of organoleptic, analytico-chemical, physico-chemical and microbiological analyzes of water samples taken from the Araz River in the Beylagan district, in the territories of the Sadarak and Ordubad districts of the Nakhchivan AR and drinking water samples, supplied to enterprises and population of the city of Nakhchivan

\begin{tabular}{|c|c|c|c|c|c|c|c|}
\hline № & Parameters & $\begin{array}{l}\text { Requirements of stan- } \\
\text { dards }(2874-82)\end{array}$ & & & Actual resu & lits & \\
\hline $\mathrm{I}$ & II & III & IV & $\mathrm{V}$ & VI & VII & VIII \\
\hline \multirow{2}{*}{1} & \multirow{2}{*}{ Transparency, cm } & $>30 *$ & $>30 *$ & & & & \\
\hline & & $>10 * *$ & - & $>30$ & $>30$ & $>30$ & $>30$ \\
\hline 2 & Turbidity, ${ }^{0}$ & $\leq 1,5$ & 0 & 0 & 0 & 0 & 0 \\
\hline 3 & Sludge & 0 or traces & 0 & 0 & 0 & 0 & 0 \\
\hline 4 & Color, ${ }^{0}$ & $\leq 20^{*}$ & 0 & 0 & 0 & 0 & 0 \\
\hline \multirow{2}{*}{5} & \multirow{2}{*}{ Odors, at $20^{\circ} \mathrm{C}$, points } & $\leq 2 *$ & 0 & $1-2$ & $1-2$ & 1 & 1 \\
\hline & & $\leq 3 * *$ & & & & & \\
\hline \multirow{2}{*}{6} & \multirow{2}{*}{ Tastes, at $20^{\circ} \mathrm{C}$ points } & $\leq 2 *$ & 0 & 2 & 2 & 1 & 1 \\
\hline & & $\leq 2 * *$ & & & & & \\
\hline 7 & Activity $(\mathrm{pH})$ & $6.0-9.0$ & 6.8 & 7.1 & 7.2 & 7.2 & 7.7 \\
\hline 8 & Dry residue, $\mathrm{mg} / \mathrm{l}$ & $100 \div 1000^{*}$ & 166 & 1645 & 1495 & 595 & 950 \\
\hline 9 & Total hardness, mg-eq/l & $7.0^{*}$ & 1.6 & 15 & 14 & 5.4 & 8.7 \\
\hline \multirow{2}{*}{10} & \multirow{2}{*}{$\begin{array}{l}\text { Hydrocarbonate hardness, } \\
\text { mg-eq/l }\end{array}$} & $<7 *$ & - & - & - & - & - \\
\hline & & are not standardized $* *$ & 0.7 & 7.1 & 6.7 & 1.4 & 2.5 \\
\hline 11 & Zinc, $\mathrm{mg} / \mathrm{l}$ & 5 & 0 & 0.01 & 0 & 0.01 & 0 \\
\hline 12 & Phenol, mg/l & 0.001 & 0 & 0 & 0 & 0 & 0 \\
\hline 13 & Sulphides, mg/l & 0.05 & 0 & 0 & 0.01 & 0 & 0 \\
\hline 14 & Iodine, (Bromine), $\mathrm{mg} / \mathrm{l}$ & $0.001-0$. standardized $* *$ & $\begin{array}{l}0.02 \\
(\mathrm{Br})\end{array}$ & $\begin{array}{l}\mathbf{0 . 1 5} \\
\text { (Br) }\end{array}$ & $\begin{array}{l}\mathbf{0 . 2} \\
(\mathrm{Br})\end{array}$ & $\begin{array}{l}0.05 \\
(\mathrm{Br})\end{array}$ & $\begin{array}{l}0.02 \\
(\mathrm{Br}) \\
\end{array}$ \\
\hline 15 & Residual chlorine, mg/l & $0-0.5^{*}$ & $0-0,01$ & 0 & 0 & 0 & 0 \\
\hline 16 & Chlorides, mg/l & $350 *$ & 36 & 55 & 238 & 90 & 90 \\
\hline 17 & Nitrates, mg/l & $45^{*}$ & 4.4 & 12.8 & 4.4 & 3.4 & 4.9 \\
\hline 18 & Cadmium, mg/l & $0 *$ & 0 & 0 & 0 & 0 & 0 \\
\hline 19 & Silver, mg/l & are not standardized $* *$ & 0 & $0-0.01$ & 0 & 0 & 0 \\
\hline 20 & Strontium, mg/l & $7.0 *$ & 0.7 & 9 & 2.5 & 2.3 & 7 \\
\hline 21 & Arsenic, mg/l & $0.05 *$ & 0 & 0.005 & 0.005 & 0.005 & 0.003 \\
\hline 22 & Iron, $\mathrm{mg} / \mathrm{l}$ & $\begin{array}{l}0.3 * \\
1 * *\end{array}$ & 0.2 & 0.2 & 1.0 & 1.0 & 0.01 \\
\hline 23 & Lead, mg/l & $0.03 *$ & 0 & 0 & 0 & 0 & 0 \\
\hline 24 & Mercury, mg/l & $\begin{array}{c}0 * \\
0.001 * *\end{array}$ & 0 & 0 & 0 & 0 & 0 \\
\hline 25 & Nitrites, mg/l & $\begin{array}{l}0-0.1^{*} \\
0.1^{* *}\end{array}$ & 0.05 & 0.1 & 0.2 & 0.1 & 0.3 \\
\hline 26 & Sulphates, mg/1 & 500 & 18 & 318 & 230 & 68 & 155 \\
\hline 27 & $\mathrm{Na}, \mathrm{K}, \mathrm{W}, \mathrm{mg} / \mathrm{l}$ & are not standardized $* *$ & $\begin{array}{c}23,9 \\
0.03 \\
\end{array}$ & $\begin{array}{c}56,12 \\
0.1 \\
\end{array}$ & $\begin{array}{c}54,18 \\
0.1 \\
\end{array}$ & $\begin{array}{c}58,22 \\
0.05\end{array}$ & $\begin{array}{c}38,9 \\
0\end{array}$ \\
\hline 28 & $\begin{array}{l}\text { E.coli, the number of bacteria in } \\
1 \text { liter }\end{array}$ & $\begin{array}{l}\leq 3 * \\
\leq 9 * *\end{array}$ & $\begin{array}{l}3 \\
3 \\
\end{array}$ & $20-26$ & $82-90$ & 20 & $30-40$ \\
\hline 29 & $\begin{array}{l}\text { Coli-titr, amount of water in } \\
\text { which } 1 \text { bacterium was detec- } \\
\text { ted, ml }\end{array}$ & $\begin{array}{l}>300^{*} \\
>100^{* *}\end{array}$ & $\begin{array}{l}333 \\
333\end{array}$ & $50-40$ & $12-10$ & 50 & 30 \\
\hline 30 & $\begin{array}{l}\text { The amount of Saprophytic } \\
\text { microorganisms in } 1 \mathrm{ml}\end{array}$ & $100 *$ & 0 & 8 & 10 & 6 & 10 \\
\hline & Aspergillus (in $1 \mathrm{ml}$ ) & & 0 & 0 & 1 & 0 & $0-1$ \\
\hline & Candida al. (in $1 \mathrm{ml}$ ) & & 0 & $6-8$ & $8-9$ & 6 & $6-9$ \\
\hline 31 & \begin{tabular}{|l|}
$\begin{array}{l}\text { Staphylococcus, Strept., (in } 1 \\
\text { 1iter) }\end{array}$ \\
\end{tabular} & 0 & $\begin{array}{l}0\left(\mathrm{St}_{\mathrm{aur}}\right) \\
0\left(\mathrm{St}_{\text {epid }}\right)\end{array}$ & \begin{tabular}{|l|}
$0\left(\mathrm{St}_{\mathrm{aur}}\right)$ \\
$16\left(\mathrm{St}_{\mathrm{epid}}\right)$ \\
\end{tabular} & $\begin{array}{l}30\left(\mathbf{S t}_{\text {aur }}\right) \\
42\left(\mathrm{St}_{\text {epid }}\right) \\
\end{array}$ & $\begin{array}{l}\mathbf{0 - 1}\left(\mathbf{S t}_{\text {aur }}\right) \text {, } \\
7-8\left(\mathrm{St}_{\text {epid }}\right)\end{array}$ & $\begin{array}{l}\mathbf{8}\left(\mathbf{S t}_{\text {aur }}\right) \\
20\left(\mathrm{St}_{\text {epid }}\right)\end{array}$ \\
\hline 32 & $\begin{array}{l}\text { Pathogenic microorganisms, in- } \\
\text { cluding Salmonella (in } 1 \text { liter) }\end{array}$ & 0 & 0 & 0-1 & $10-13$ & $3-6$ & $6-10$ \\
\hline
\end{tabular}


Note: * - standard for drinking water; ** - standard requirement for spring water and water for technical use; IV samples of water taken from the water pipeline, supplying the city of Nakhchivan and its population with drinking water; V - samples of water taken from Araz river at the crossing of the Sadarak region of the Nakhchivan Autonomous Republic bordering with Turkey and Armenia; VI - samples of water taken from Araz river on the territory of the Sadarak region after the Customs Transition Gate; VII - samples of water taken from Araz river at the intersection of the territory of the Ordubad region with the borders of the IIR and Armenia; VIII - samples of water taken from Araz river at the crossing of the Beylagan district's territory with the boundary of the IIR.

The results of microbiological analyzes presented in Table 3 show that the pathogenic microorganism's count in each liter samples of water taken from Araz River at the crossing of the Sadarak region of the Nakhchivan Autonomous Republic with the borders of Turkey and Armenia is above the maximum permissible norm, following the direction of the river flow after the Customs Transition Gate in the Sadarak region the microorganism's count in the water of the Araz River is increasing. This count is significantly reduced in the Araz river at the intersection of the Ordubad region with the borders of the IIR and Armenia. However at flowing through parts of the territory of Armenia in these samples of water taken from the Araz River at the point of crossing the territory of the Beylagan region with the boundary of the IRR the pathogenic microorganism's count is increasing, i.e. the following pollution of the Araz River occurs at the intermediate area situated between Ordubad and Beylagan.

The results of the alanalytico-chemical and physico-chemical analyzes presented in Table 3 show that total quantity of inorganic substances in water samples taken from Araz River at the crossing of the Sadarak region of the Nakhchivan Autonomous Republic with the borders of Turkey and Armenia is above the maximum permissible norm for drinking water by 3 times, the total quantity of inorganic compounds along the path of the river to the Ordubad region naturally decreases by a factor of 3 due to partial adsorption on silt soils, but in Beylagan-Imishli territory it is again increased by $50 \%$, in river water, when the river enters the territory of Sadarak region, the concentration of strontium $\left({ }^{88} \mathrm{Sr}\right)$ is $30 \%$ higher than the maximum permissible norm, this concentration along the path of the flow of the river to the Ordubad region is naturally reduced by a partial adsorbtion on the silt-soils by 3-4 times, but in
Beylagan-Imishli territory again increases by 23 times, the relative amount of sulphates and nitrates from Sadarak to Ordubad declining by 4-5 times, in Beylagan-Imishli territory again increased by 2 times.

The results of analytico-chemical, physico-chemical and microbiological analyzes show contamination by organic and inorganic emissions of the Araz river when it reaches the territory of the Sadarak region and its further contamination through parts of the territory of neighboring countries, located between the Ordubad region of Nakhchivan AR and Beylagan district.

In addition to the inrease of microorganism's count the concentration of chlorides and other halides, nitrites, sulphides, alkalineunderground metals in the water of the Araz River in the Sadarak region is also relatively increased up to the permissible limits, which is explained by the saturation of the Sadarak area with these compounds and the following pollution of the river water by organic emissions after the Customs Transition Gate.

Despite the fact that the water of the Araz river is mostly cleared from inorganic pollutants naturally by adsorbtion on the silt-soil floort downstream from the territory of the Sadarak region to the Ordubad area, but to the Beylagan region, when passing through the territories of neighboring states, water of Araz river is polluted again by inorganic and organic emissions (an increase in the relative amount of inorganic substances, including strontium, sulphates, nitrates and nitrites, in addition to an increase of microorganism's count). This fact agrees well with the results of sensory, analytic-chemical, microbiological and physico-chemical analyzes of soil and water samples taken from these areas.

Nitrite-containing compounds were detected in the water samples taken from the Araz river, despite the fact that the probability of 
finding nitrite-containing compounds in current waters is generally negligible.

The formation of nitrites from nitratecontaining salts of alkaline earth metals occurs at sufficiently high temperatures (400-500):

$2 \mathrm{KNO}_{3} \stackrel{T, K}{\longrightarrow} 2 \mathrm{KNO}_{2}+\mathrm{O}_{2}$.

The disproportionation of nitrogen dioxide/nitrogen(IV) oxide/in alkaline media (reaction 2) also occurs in water (reaction 3):

$$
\begin{aligned}
& 2 \mathrm{NO}_{2}+2 \mathrm{NaOH} \rightarrow \mathrm{NaNO}_{3}+\mathrm{NaNO}_{2}+\mathrm{H}_{2} \mathrm{O}, \\
& 2 \mathrm{NO}_{2}+\mathrm{H}_{2} \mathrm{O} \rightarrow \mathrm{HNO}_{3}+\mathrm{HNO}_{2} .
\end{aligned}
$$

However, the process of absorption of nitrogen dioxide on the surface of river water and reaction (3) is characterized by low rates and consequently, the observed maximum permissible and higher concentrations of nitrites in the water of the Araz River can not be explained only by reaction (3). As noted above, pollution of the Araz River with anthropogenic emissions and observed higher than the maximum permissible concentrations of inorganic compounds, including the revealed high concentrations of chlorine-containing compounds (chlorides, hypochlorides, chlorates etc.) in river water and chlorine-containing salts in the soil of Nakhchivan AR show that the formation of nitrites in the water of the Araz River is accompanied by the processes entering the mechanism of nitrite formation in chlorine-containing waters [3]:

$$
\begin{aligned}
& \mathrm{NO}_{2}+\mathrm{ClO} \rightarrow \mathrm{ClNO}_{3}, \\
& \mathrm{ClNO}_{3}+\mathrm{H}_{2} \mathrm{O} \rightarrow \mathrm{HOCl}+\mathrm{HNO}_{3}, \\
& 4 \mathrm{Mg}(\mathrm{Ca}, \mathrm{Zn})+10 \mathrm{HNO}_{3} \text { (slightly acidic) } \rightarrow \\
& 4(\mathrm{Ca}, \mathrm{Zn}) \mathrm{Mg}\left(\mathrm{NO}_{3}\right)_{2}+\mathrm{N}_{2} \mathrm{O} \text { (NO) }+5 \mathrm{H}_{2} \mathrm{O},(6) \\
& 3 \mathrm{Cu}(\mathrm{Pb})+8 \mathrm{HNO}_{3} \text { (slightly acidic) } \rightarrow \\
& 3(\mathrm{~Pb}) \mathrm{Cu}\left(\mathrm{NO}_{3}\right)_{2}+2 \mathrm{NO}_{2}+4 \mathrm{H}_{2} \mathrm{O}, \\
& \mathrm{N}_{2} \mathrm{O}+\mathrm{NO} \rightarrow \mathrm{N}_{2}+\mathrm{NO}_{2}, \\
& \mathrm{NO}_{2}+\mathrm{NO}_{2} \rightarrow \mathrm{N}_{2} \mathrm{O}_{4}, \\
& \mathrm{~N}_{2} \mathrm{O}_{4}+\mathrm{H}_{2} \mathrm{O} \rightarrow \mathrm{HNO}_{2}+\mathrm{HNO}_{3}, \\
& 2 \mathrm{HNO}_{2}+\mathrm{Mg}\left(\mathrm{HCO}_{3}\right)_{2} \rightarrow \mathrm{Mg}\left(\mathrm{NO}_{2}\right)_{2}+ \\
& +2 \mathrm{H}_{2} \mathrm{CO}_{3} .
\end{aligned}
$$

As can be seen from the above mechanism molecules of atmospheric nitrogen dioxide and the $\mathrm{ClNO}_{3}, \mathrm{NO}_{2}, \mathrm{~N}_{2} \mathrm{O}_{4}$ molecules formed in the reactions (4), (6), (7), (8), (9) by the reactions (3), (5), (10) with water here are formed the nitrate acid molecules (slightly acidic medi- um). The water minerals in slightly acidic medium by slow reactions (6) and (7) are formed the nitrogen oxides. Molecules of nitrite acid formed in reactions (3) and (10) of nitrogen oxides with water by the reaction (11) with hydrocarbons provide to formation of small concentrations of stable nitrite compounds in the water of the Araz river.

It should be noted that, there are no production enterprises near the site of the arrival of the Araz River to the territory of the Sadarak region from mount Agri of Turkey, on the sites in the territory of IIR bordering with the territory from Nakhchivan AR to the Beylagan region of Azerbaijan and the small rivers flowing alongside the central industrial regions of Armenia merge into the Araz river. Therefore, it can be concluded that in both cases (before Sadarak and after Ordubad districts) the Araz River is polluted from the Armenian territories.

The chemical composition, sensory, physico-chemical and microbiological characteristics of water samples taken from the parts close to the surface and to the bottom of the Araz River on the Sadarak region bordering with Turkey and Armenia, after the Customs Transition Gate in the Sadarak region in the area of the Ordubad district of the Nakhchivan AR bordering with IIR and Armenia and in the Beylagan-Imishli district do not meet the requirements of the AZS 282 standard for drinking water.

The chemical composition, organoleptic, physico-chemical and microbiological characteristics of water samples taken for the comparative analysis from the water supply pipeline provides industrial enterprises and the population of $\mathrm{Na}-$ khchivan with drinking water meet the requirements of the standard AZS 282 for drinking water and is suitable for use as drinking water.

Results of the experiments for disinfection of water samples taken from Araz river by $1 \mathrm{mg}$ calcium perchlorate (solution of $1 \mathrm{mg}$ of calcium perchlorate with $60 \%$ active chlorine in $5 \mathrm{ml}$ of distilled water is added to 1 liter of river water) have shown that after 1 hour in a river water sample the microorganism's count is reduced approximately by $10 \%$ and the absence of residual chlorine. The results of experiments with 2 
mg calcium perchlorate showed that after 1 hour in samples of river water the microorganism's count decreased approximately by $2-3$ times and the absence of residual chlorine. Experiments on sterilization with $5 \mathrm{mg}$ of calcium perchlorate showed the absence of microorganisms and residual chlorine after 1 hour in samples of river water. Experiments on sterilization with $10 \mathrm{mg}$ calcium perchlorate showed that after 1 hour in the samples of river water there are no microorganisms, and the residual chlorine concentration is below the maximum permissible value for residual chlorine $(<0.5 \mathrm{mg} / \mathrm{l})$ for drinking water.

Higher amounts of calcium perchlorate along with the total clearance of all microorganisms in contaminated river water lead to the accumulation of residual chlorine in quantities higher than the maximum permissible values for drinking water. The amount of calcium perchlorate in the range of 5-10 mg (optimal value) is sufficient for the total clearance of all microorganisms in contaminated water taken from Araz river and the accumulated amount of residual chlorine does not exceed the maximum permissible value.

The results of experiments on disinfection by ionizing radiation of water samples taken from the Araz River in which microorganisms were detected are shown in Figure.
As can be seen from Figure 1, the irradiation by absorbed dose 5 kGy (optimal parameter) of ionizing radiation ensures complete extermination of all microorganisms in water samples taken from the Araz River, which were contaminated by organic emissions and microorganisms.

Thus, both chemical (chlorination with perchlorates) and radiolytic (irradiation with ionizing radiation) methods of disinfection of the contaminated water of the Araz River are sufficiently highly efficient methods of purification.

Radiometric measurements, sampling and analyzes were conducted in July-August of 2016 and are planned to continue these studies.

On the basis of the experimentally obtained results and proceeding from the observed process of slow natural self-purification of water (partial adsorption of inorganic pollutants on the silt-soils) of Araz River on the way to the territory of the Beylagan-Imishli region, it is possible to purify deeply the Araz River water in Nakhchivan AR by passing through a thermally regenerated and periodically updated a large adsorbent-sand filter after chemical or radiolytical disinfection of river's water.
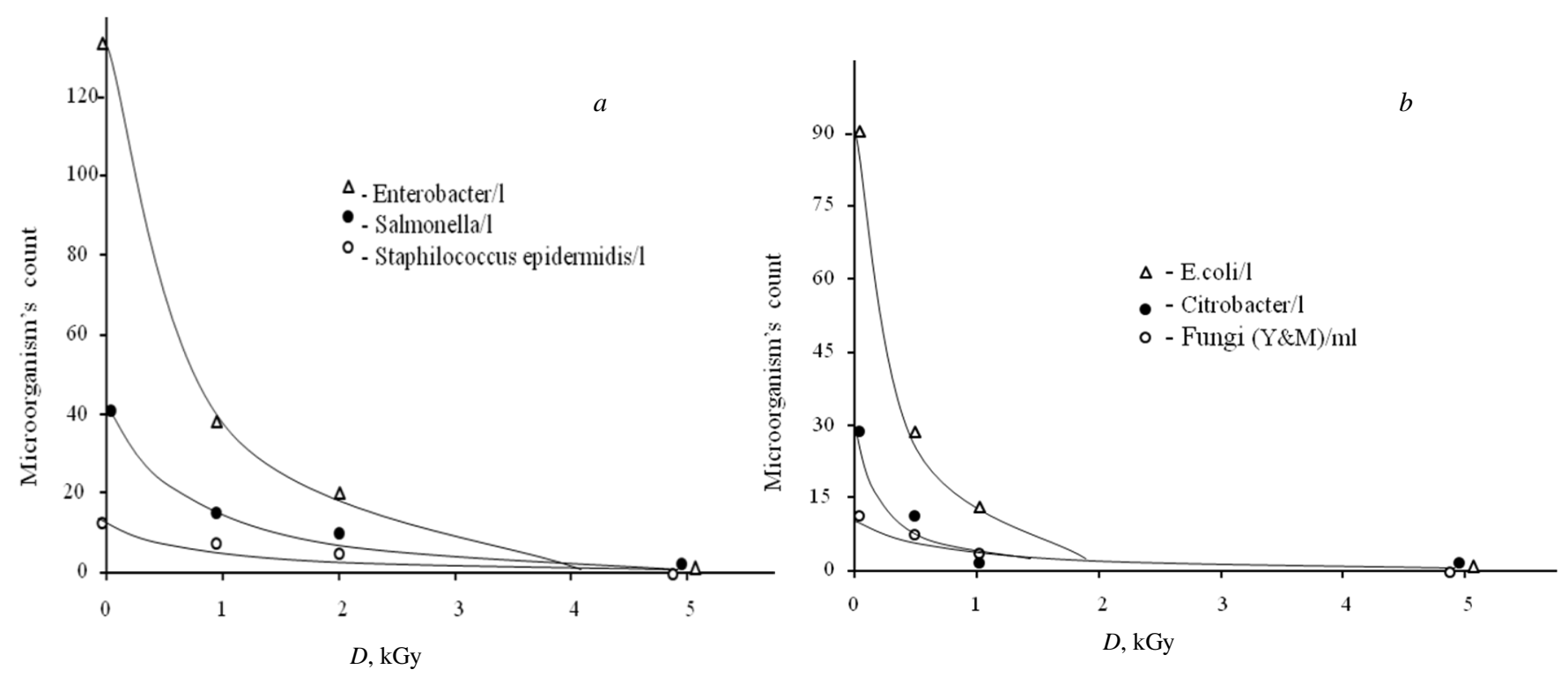


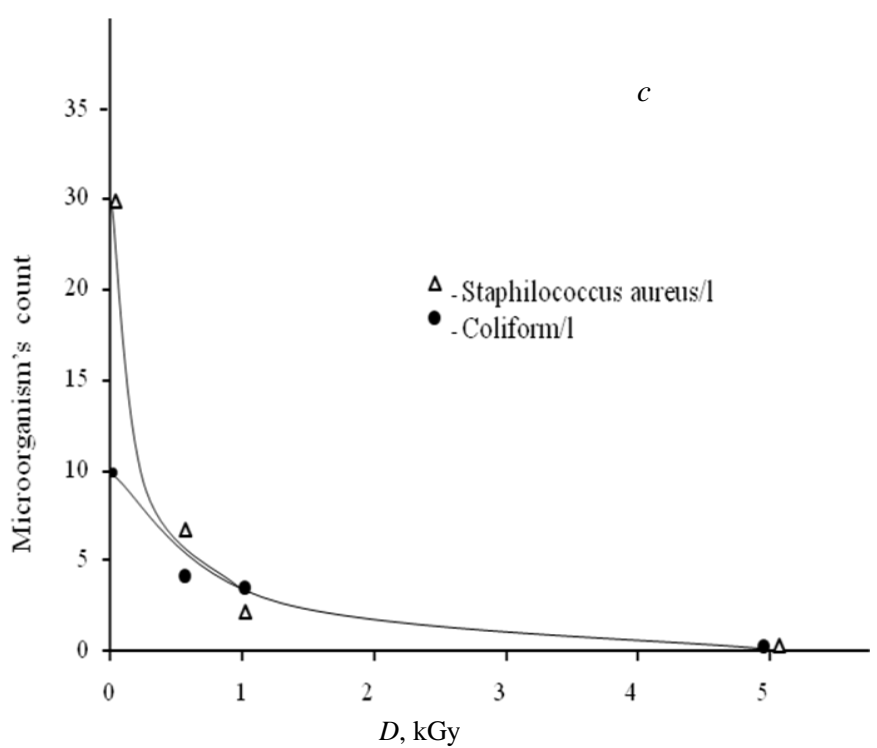

\section{References}

1. Qəribov A.A., Məmmədov X.F. Təbii politsiklik toksinlərin sulu məhlullarında fotolitik proseslər // Azərbaycan Milli Elmlər Akademiyasının məruzələri. 2012. № 3. S. 64-69.

2. Məmmədov X.F. Mikotoksinlərin sulu məhlullarında radiolitik proseslər // Azərb. kimya jurnalı. 2012. № 4. S. 75-84.

3. Məmmədov X.F. Qapal1 su mənbələrinin xlorlanmış sularında nitritlərin yaranma kinetikası // Elmi Osərlər - Fundamental Elmlər. Kimya. 2012. № 1. Cild XI (41). S. 163-165.

4. Mamedov Kh.F. Fotoliticheskaia i radioliticheskaia detoksikatciia i sterilizatciia kombikormov, zarazhennykh kishechnymi palochkami i gribkami Aspergillus // Uchenye Zapiski Tavricheskogo Natcionalnogo Un-ta im. V.I.Vernadskogo. 2011. T. 24. № 3. S. 138-140.

5. Mamedov Kh.F., Kurbanov M.A., Mustafaev I.I., Aliev A.G., Mamedova F.V., Bakhtiiarova N.T. Radioliticheskoe razlozhenie 3,4-benzpirena $\mathrm{v}$ razbavlennykh vodnykh rastvorakh // Himiia vysokikh energii. Moskva. 2015. T. 49. № 5. S. 354-355.

6. Romanenko G.A. Problemy tekhnogennogo vozdeistviia na agropromyshlennyi kompleks i rea-
Reducing the microorganism's count in water samples taken from the Araz River, depending on the value of the absorbed dose of ionizing radiation.

\section{ARAZ ÇAYININ KSENOBIOTTIKLORLə VӘ PATOGEN MIKROORQANIZMLORLӘ ÇİRKLONMə SəVIYYYSINIIN TəDQIQI, SU NÜMUNəLəRININ KIMYəVI Və RADIOLITIK ÜSULLARLA TəMIZLONMӘSI}

\section{X.F.Məmmədov, A.M.Güləmirov, R.Q.Qəribov, Q.R.Allahverdiyev, H.N.Şirəliyeva, A.R.Đlihüseynova, N.A.Mirzayev}

Araz çayının axarı boyu ətraf ərazilərdə radioaktiv fonun ölçülməsi və çaydan götürülmüş çoxsaylı su nümünələrinin kompleks orqanoleptik, analitik-kimyəvi, fiziki-kimyəvi və mikrobioloji analizləri aparılmışdır. Antropogen ksenobiotiklərlə və patogen mikroorqanizmlərlə çirklənmiş su nümunələrinin kimyəvi və radiolitik üsullarla təmizlənməsi və dezinfeksiyası proseslərinin optimal parametrləri təyin edilmişdir.

Açar sözlor: ksenobiotiklər, radionüklidlər, ağır metallar, mikroorqanizmlər, radiolitik dezinfeksiya. 


\section{ИССЛЕДОВАНИЕ УРОВНЯ ЗАГРЯЗНЕНИЯ РЕКИ АРАЗ КСЕНОБИОТИКАМИ И ПАТОГЕННЫМИ МИКРООРГАНИЗМАМИ, ХИМИЧЕСКИЕ И РАДИОЛИТИЧЕСКИЕ СПОСОБЫ ОЧИСТКИ ПРОБ ВОДЫ}

Х.Ф.Мамедов, А.М.Гюламиров, Р.Г.Гарибов, Г.Р.Аллахвердиев, Х.Н.Ширалиева, А.Р.Алигусейнова, Н.А.Мирзаев

Проведены измерения радиационного фона на близлежащих территориях вдоль течения реки Араз и комплексные органолептические, аналитико-химические, физико-химические и микробиологические анализы проб речной воды. Определены оптимальные параметры процессов химической и радиолитической дезинфекции и очистки водных проб, загрязненных антропогенными ксенобиотиками и патогенными микроорганизмами.

Ключевые слова: ксенобиотики, радионуклиды, тяжелье металль, микроорганизмы, радиолитическая дезинфекичия. 